\title{
Factors that Affect the Productivity of Palm Oil Plantations Self-Help Patterns in Jambi Province
}

DOI: https://doi.org/10.47175/rissj.v2i4.321

\author{
1,2,3 Department of Agribusiness, \\ Faculty of Agriculture, \\ University of Jambi, Indonesia
}

| Saidin Nainggolan ${ }^{1 *}$ | Mirawati Yanita² | Manuel Leonardo ${ }^{3}$ |

*saidinnainggolan64@gmail.com

\section{ABSTRACT}

This study aims to analyze factors that affect the productivity of oil palm plantations in Jambi Province. This research was conducted in sentra palm oil production in Merangin Regency with the research locus of South Veil Subdistrict selected purposive. The data used consists of Primary Data that includes social factors, economic factors, behavior of the use of production inputs and productivity of oil palm plantations.. The sample size is 80 farmers. Sample withdrawal by Simple Random Sampling method Restoration of structural models factors that affect the productivity of oil palm plantations is used sem Partial Least Squaremodel. The results showed that social factors, economic factors and institutional access factors were in the moderate category. The productivity of oil palm plantations is relatively low. Manifest social factors, which have a very real effect is the age of farmers. Manifest market access and product prices have a very real effect on economic factors. Manifest access to fertilizer procurement and fertilizer prices has a very real effect on the behavior of the use of production inputs and moderation variables that have a significant effect on the productivity of oil palm plantations. Policies that need to be done to improve. Is the strengthening of economic factors in the field of product prices and market access, and upay6a strengthening the behavior of farmers in the use of production inputs, especially fertilizers by providing subsidy incentives.

KEYWORDS

oil palm plantation; productivity; socioeconomic; production input.

\section{INTRODUCTION}

Traditional farmers are characterized by a relatively small, dispersed, subsistence business scale, low adoption of new technologies and low palm oil plantation productivity. The emergence of traditional plantations occurs due to the influence of social factors, economic factors, institutional access and the lack of ability of farmers in the use of production inputs as recommended. This low garden productivity occurs due to the limited ability of farmers to utilize available economic capabilities. There is a very complex link between social factors and economic factors to productivity. Economic factors with willingness to use production inputs to productivity, social factors with moderation of the use of production inputs against the productivity of oil palm plantations.

Ardiansyah et al (2018) and Indrawati (2015) that socio-economic factors, and institutional access can be said to be determinants of farmers' performance, the commercialization of gardens is largely determined by the ability of farmers to utilize 
economic resources. Differences in the ability to allocate economic resources will cause differences in terms of productivity achievement. This social factor determines the mindset of farmers in economic decision making so as to determine the success of increased productivity. Economic factors, especially product prices and access to sales, determine the scale of production that farmers will strive for and become determinants of the productivity of oil palm plantations. Institutional access factors to the procurement of production inputs, credit, and to cultivation technology are the defining variables in access to the availability of working capital, the availability of production inputs on time and the adoption of new technologies. The increase in the productivity of oil palm plantations is determined by the ease and ability by farmers to institutional access. The success of increasing the productivity of oil palm plantations is also determined by the ability of farmers in the allocation of the use of production inputs, and this factor is largely determined by social, economic and farmers' access to institutions. From this description, the purpose of the study is to examine the factors that affect the productivity of self-help oil palm plantations in Jambi Province.

\section{RESEARCH METHODS}

The subject of the study was a self-help patterned palm oil farmer in Jambi Province. The study was conducted from March to August 2021. The research was conducted by taking one district as a sample of the area, namely Merangin Regency with the focus of South Veil Subdistrict research. The location of this study was taken purposively with the consideration that the regency is a center of self-help oil palm plantations in Jambi Province. The number of maps, ni sawti in Merangin Regency there are as many as 33,465 farmers, and for South Tabi subdistrict there are as many as 14,680 farmers. The sample group drawn as respondents were farmers who had a plant age of 8-20 years. Determination of the number of samples using the slovin method. The sample size used as many as 80 farmers. The method of selecting samples is done by simple random sampling using random tables. The data analysis method uses theSEM-Partial least squareapproach. The structural model is used as follows.

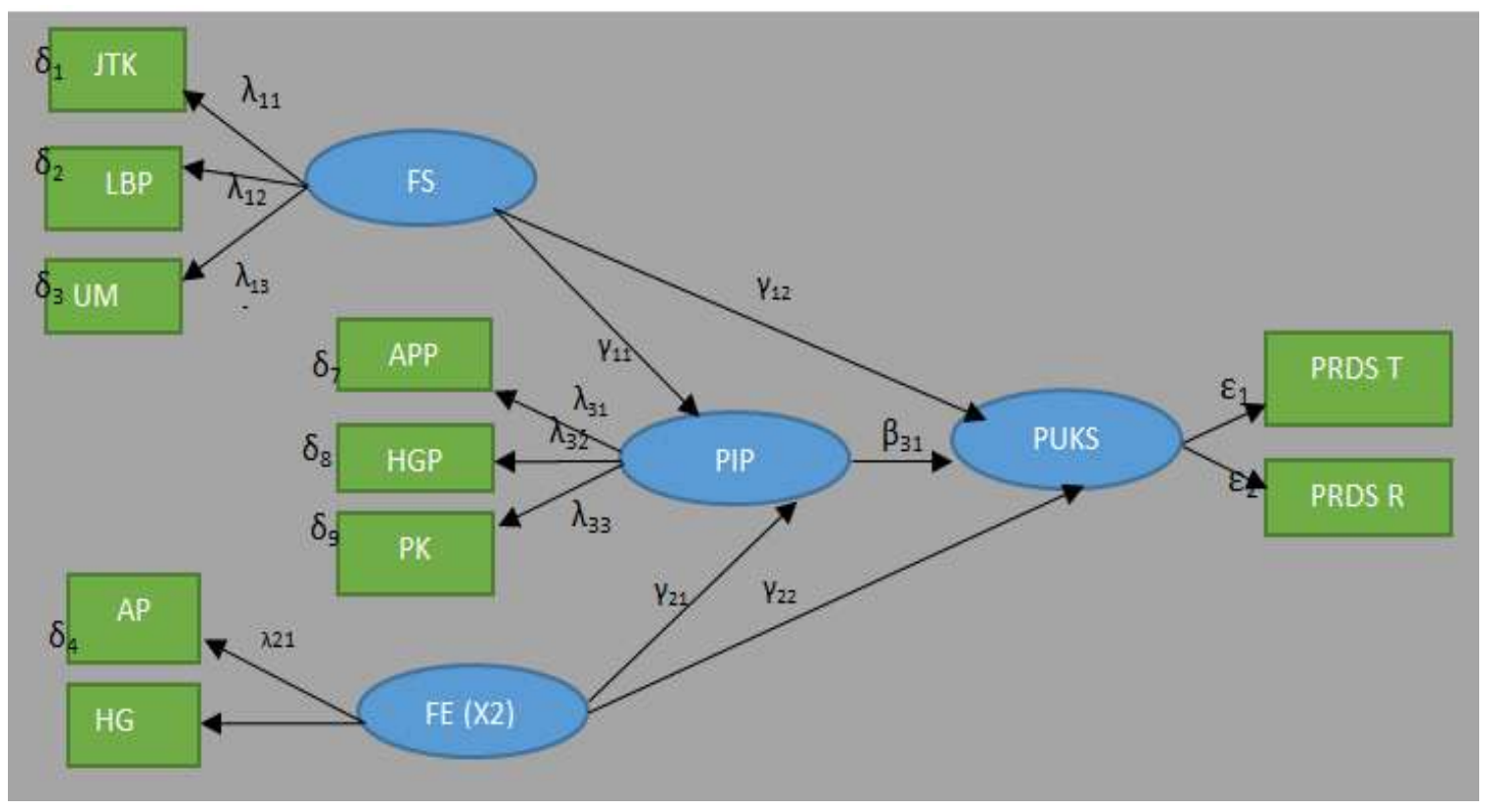

Figure 1. Research Structural Model Diagram 
FS $=$ Social Factors

JTK = Number of Family Dependents

LBP $=$ Background of Farmer Origins

$\mathrm{FE}=$ Economic Factors

$\mathrm{AP}=$ Sales Access (Market)

$\mathrm{HG}=$ Product Price

$\mathrm{UM}=$ Age

TK = Labor

PIP $=$ Use of Production Inputs

APP $=$ Fertilizer Procurement Access

HGP $=$ Fertilizer Price

$\mathrm{PK}=$ Chemical Fertilizer

PRDV = Palm Oil Plantation Productivity

PRDV R = Low Productivity

PRDV T $=$ Productivity Tnggi

Criteria in analyzing the SEM - PLS model through stages are:

1. Model match test refers to Jaya and Sumertajaya (2008), Latan H (2012), Hair et al (2014) Gunarto (2018) and Nainggolan F V et al (2019) consisting of:

- Measurement Model(Outer model)

a. Convergent validity, the loading factor value of 0.5 to 0.6 is considered sufficient.

b. Discriminant validity, construct AVE value $>0.50$ or cross loading value $>$ 0.70 , it has been good in representing its latent (Jaya and Sumertajaya, 2008).

c. Composite reliability $(\mathrm{pc})$, composite realibility value $0.6-0.7$ acceptable

- Structural Model(Inner Model)

The model has predictive relevance if the value of ${ }^{\mathrm{Q} 2}>0$. Value ${ }^{\mathrm{Q} 2}=1-\left(1-\mathrm{R}_{1}{ }^{2}\right)(1-$ $\mathrm{R}_{2}{ }^{2) \ldots}\left(1-\mathrm{R}_{\mathrm{p}}{ }^{2)}\right.$. The $\mathrm{R}$-square value is the dependent variable value in the equation model. The model will be better if the $\mathrm{Q}^{\mathrm{Q}}$ niai approaches 1

2. Hypothesis testing, if the $p$-value $\leq \alpha(0.05)$ can be said to be significant and vice versa.

\section{RESULTS AND DISCUSSION}

\section{Description of Farmers, Oil Palm Plantations and Factors that Affect Productivity}

Farmers are mostly of productive age. There are $77.5 \%$ of farmers are in the productive age of $26.5-\leq 60$ years. Farmers are mostly formally educated at primary school level $(61.35 \%)$ so it will affect decision-making patterns in oil palm plantations. Palm oil gardening experience is relatively high with an average of 18.4 years. This experience helps farmers in the allocation of the use of production inputs. The land area is ranging from 1.8-6.5 hectares per farmer with an average of 4.8 hectares per farmer. $96.5 \%$ of farmers are farmers who own the cataiser. The number of dependents of farming families averages 4--5 people so that the depedenncy ratio is relatively high.

Oil palm plantations are generally managed with the concept of integrated crop management. There are $78.2 \%$ of farmers following the PTT pattern and $21.8 \%$ of farmers do not follow the PTT pattern. PTT includes the use of superior varieties, $81.8 \%$ of farmers use marihot superior seedlings and $18.2 \%$ of farmers use sucofindo seeds. The number of trees has 132-156 perhektar stems. Planting distance of $6 \times 7 \mathrm{~m}$ with a pattern of the ranks 
of the injang. Farmers fertilize in quantities and times not in accordance with the recommended dose. Fertilizers used are fertilizers (NPK) and liquid waste. NPK fertilizer used $250 \mathrm{~kg} /$ ha for one application and liquid waste fertilizer 850 liters / ha. Dolomite 800 $\mathrm{kg} / \mathrm{ha}$, average age of plants with a 10-15 years. Productivity of 16.8 tons / ha per year.

\section{Estimated Factors Affecting Productivity}

The test results of the measurement model include (1) Convergent Validity: indicators of The Number of Family Dependents (JTK), Farmer Background (LBP), Age (UM), Sales Access (AP), Price (HG), Access to Fertilizer Procurement (APP), Fertilizer Price (APP), Fertilizer Price (HGP), Chemical Fertilizer (PK), Land Area (LL), and Produtivity (PRDV) qualify valid because it has an outer loading value greater than 0.7 and AVE above $0.5 ;$ (2) Discriminant Validity is good because the AVE average value $\geq 0.5$; and (3) Composite validity variables have qualified reliable. Structural models(inner models) have a high predictive relevance with ${ }^{\mathrm{Q} 2}+0.941>0$ indicating that $94.1 \%$ of research data can be explained by structural models.

\section{Variable Construct Test Results in Path Diagram}

The variable value in the study was obtained from the algorithm processed results from PLS software judging from the R-squarevalue.

Table 1. Variable Construct Restoration Results in Path Diagram

\begin{tabular}{l|l|l|}
\hline \multicolumn{1}{c}{ R Squared } & R Square Adjusted \\
\hline PIP & 0,686 & 0,678 \\
\hline PRDV & 0,812 & 0,804 \\
\hline
\end{tabular}

Source: Smart PLS Processed Data Results Version 3,0,2020

Table 1 shows an $R$-suqared (R2) of $\geq 0.67$ identifying that the model is categorized as good. $R$-squared results between 0.33 and $0.67 R$-squared ${ }^{(\mathrm{R} 2)}$ results identified that the model was categorized as moderate. While the $R$-squared ${ }^{(\mathrm{R} 2)}$ result below 0.33 identified that the model was categorized as weak (Jayaand Sumertajaya,2014). These values will be easier to understand by looking at the path diagram. Adapun image of the path diagram can be seen Figure 1.

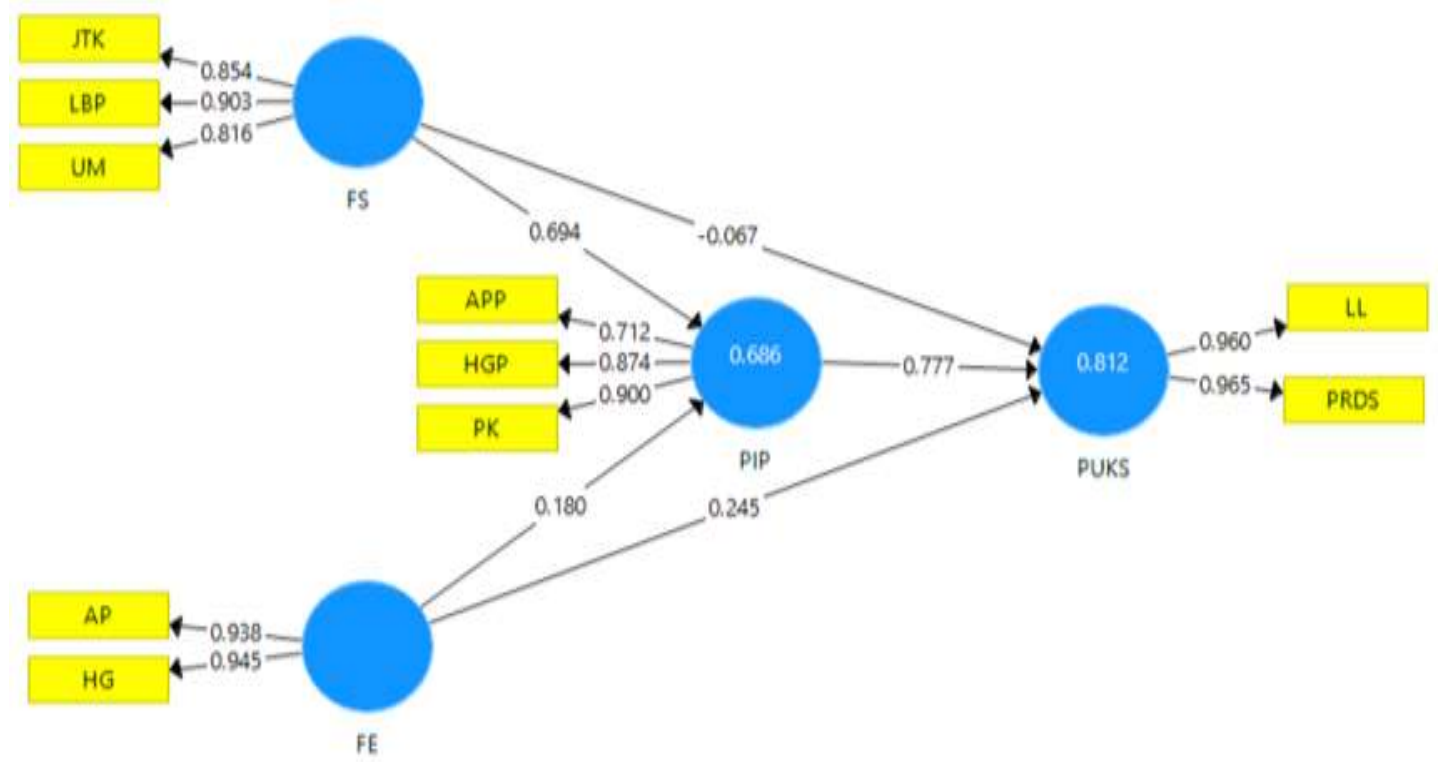

Figure 2. Diagram of the path of the results of the study 
Based on the above equation, it can be known that social factors can be reflected by the use of production inputs of 0.694 and the productivity of palm oil farmers by -0.067 . Economic factors can also be reflected by the development of production inputs of 0.180 and the produtivity of palm oil farmers by 0.245 .

\section{Influence Analysis Between Variables}

The coefficient of the path that is positive or negative with the calculation of $p$-value $<\alpha$ (0.5) means that the variable has a significant effect. The relationship between latent constructs can be seen table 2 below:

Table 2. Direct and Indirect Influence of Social and Economic Factors on Palm Oil Plantation Productivity in Research Areas, 2021

\begin{tabular}{|l|l|l|l|l|l|}
\hline $\begin{array}{l}\text { Relationships } \\
\text { between Variables }\end{array}$ & \multicolumn{1}{l}{$\begin{array}{l}\text { Path } \\
\text { Coefficient }\end{array}$} & Average sample & \multicolumn{1}{l}{$\begin{array}{l}\text { Standard } \\
\text { Deviation }\end{array}$} & \multicolumn{1}{l}{$\begin{array}{l}\text { t- } \\
\text { statistics }\end{array}$} & P Value \\
\hline FS-> PIP & 0,694 & 0,909 & 0,043 & 0,902 & 0,000 \\
\hline FS -> PRDV & $-0,067$ & $-0,458$ & 0,212 & 249 & 0,454 \\
\hline FE -> PIP & 0,180 & 0,068 & 0,059 & 150 & 0,070 \\
\hline FE -> PRDV & 0.245 & 0,326 & 0,086 & 787 & 0.001 \\
\hline PIP -> PRDV & 0,777 & 1,037 & 0,206 & 008 & 0,000 \\
\hline Indirect Influence & \multicolumn{5}{|l|}{} \\
\hline FS -> PIP -> PRDV & 0,540 & 0,537 & 0,098 & 503 & 0,000 \\
\hline FE -pip > ->PRDV & 0,140 & 0,138 & 0,072 & 951 & 0,052 \\
\hline
\end{tabular}

Table 2 shows that social actorsdirectly have a positive and significant effect on the use of production inputs but negative and insignificant influence on the productivity of oil palm plantations andwhatis interpreted that directly every strengthening of social factor variables by $10 \%$ will strengthen the variable use of production inputs by $6.94 \%$, but weaken the productivity variable. itas of $0.67 \%$. Feconomic actors directly have a positive but insignificant effect on the use of production inputs, but have a positive and very significant effect on agricultural productivity.. The use of production inputs directly affects positively and significantly on agricultural productivity. This is in line with Efendy, Z. (2012), Alfayanti (2013), and Nainggolan et al (2019) that the potential for increased productivity is available by $27.27-48.44 \%$ with the allocation by the use of production inputs as recommended.

\section{Analysis of Factors Affecting Between Variables}

The construct variables (latent) in the study there are four, namely social factors, economic factors, the use of production inputs and productivity of oil palm plantations. The influence of the indicator on its latent variables can be seen in Table 3 .

Table 3. Effect of Indicators on Latent Variables

\begin{tabular}{|l|l|l|l|l|l|}
\hline \multicolumn{7}{|c|}{} & $\begin{array}{l}\text { Original } \\
\text { Sample } \\
\text { (O) }\end{array}$ & $\begin{array}{l}\text { Sample } \\
\text { Mean (M) }\end{array}$ & $\begin{array}{l}\text { Standard } \\
\text { Deviation } \\
\text { (STDEV) }\end{array}$ & $\begin{array}{l}\text { T-Statistics } \\
\text { (O/STDE) }\end{array}$ & P-Value \\
\hline JTK <- FS & 0.854 & 0.856 & 0.030 & 28,050 & 0,000 \\
\hline LBP <- FS & 0.903 & 0.901 & 0.021 & 43,488 & 0,000 \\
\hline UM <- FS & 0.816 & 0.815 & 0.039 & 20,845 & 0,000 \\
\hline AP <- FE & 0.938 & 0.937 & 0.015 & $62,, 843$ & 0,000 \\
\hline HG <- FE & 0.945 & 0.945 & 0,009 & $101,, 310$ & 0,000 \\
\hline
\end{tabular}




\begin{tabular}{|l|l|l|l|l|l|}
\hline APP <- PIP & 0,712 & 0,705 & 0.071 & 1.048 & 0,000 \\
\hline HGP <- PIP & 0.874 & 0,876 & 0.021 & 43,488 & 0,000 \\
\hline PK <- PIP & 0,900 & 0,901 & 0.017 & 53,601 & 0,000 \\
\hline LL<- PRDV & 0.965 & 0.965 & 0.006 & 167,212 & 0,000 \\
\hline PRDS <-PRDV & 0,816 & 0,815 & 0.039 & 20,845 & 0,000 \\
\hline
\end{tabular}

Table 3 shows that all manifests in the model have been able to reflect their latent constructs. First, the number of dependents of thefamily, the background of the origin of farmers and age together as manifest variables that are able to explain social factors. These variables are in line with the research of Thamrin et al., (2012), Adiansyah et al (2018), and Nainggolan et al (2019) that the social factors of farmers determine the behavior of farmers in the face of productivity risks.

Second, access sales and prices together as manifest variables that are able to explain economic factor variables. Where the amount of sales access is 0.938 and the price is 0.945.. Third, access to fertilizers, fertilizer prices, and chemical fertilizers together as manifest variables that are able to explain the variable use of production inputs. Where the magnitude of the coefficient of access to fertilizer sales is 0.712 , fertilizer prices are 0.874 and chemical fertilizers are 0.900.. This is in line with Ginting IE (2017), Anto (2017), and Nainggolan et al (2019) that the availability of fertilizer, affordable prices and can be obtained at the time needed is a factor that determines the increase in the allocation of fertilizer use in oil palm plantations.

Fourth,land area and production together as manifest variables that are able to explain the variables of palm oil productivity. The amount of land area coefficient is 0.961 , and production is 0.965 . That is, every time there is a strengthening of the manifest land area and production as much as $10 \%$, there will be a strengthening of palm oil productivity variables as much as $9.61 \%$, and $9.65 \%$.

\section{CONCLUSION}

Strengthening social factors directly through manifest variables (number of family dependents, background of farmer origin, and age) will reduce palm oil productivity and has no significant effect and any increase in social factors indirectly through variable moderation of procurement of production inputs through manifest variables (access to fertilizer procurement, fertilizer prices, and chemical fertilizers) will increase palm oil productivity and have a significant effect. Any increase in economic factors directly through manifest variables (access to sales and prices) will increase the productivity of oil palm plantations that have a significant effect and every increase in economic factors directly through variable moderation of the use of production inputs will increase the productivity of oil palm plantations insignificantly. Policies that need to be done to improve. Is the strengthening of economic factors in the field of product prices and market access, and upay6a strengthening the behavior of farmers in the use of production inputs, especially fertilizers by providing subsidy incentives.

\section{REFERENCES}

Alfayanti. (2013). Analysis of Factors Affecting People's Palm Oil Production in Mukomuko Regency. Faculty of Agriculture, University of Bengkulu.

Anto. (2017). Analysis of Factors Affecting People's Palm Oil Production of Self-Help Patterns in Kampar Riau Regency. Thesis. Faculty of Agriculture, Lancang Kuning University, Pekanbaru. 
Ardiansyah, W Susilawati, IS Asnawati. (2018). Influence of Socio-Economic Factors of Corn Production District VII Koto Tebo Regency. Journal of Agri Science 2(1): 17-23.

Efendy, Z. (2012). Analysis of Factors Affecting People's Palm Oil Production in Seluma Regency. Bengkulu Agricultural Technology Assessment Center.

Ginting, J.E. (2017). Analysis of Factors yang Influential thadap Palm Oil Productivity in Plasma Plantation PT. MNIS Indra Sakti. AGROMAST JOURNAL, Vol.2, No.2.

Gunarto M. 2018. Statistical Analysis with Structural Equation Model (SEM): Theoretical $\&$ Practical. Bandung. Alphabet

Hair, et al. (2014). Multivariate Data Analysis. New International Edition. New Jersey : Pearson.

Jaya I Gede NM, and IM Sumertajaya. (2008). Structural Equation Modeling With Partial Least Square. Teaching Staff of the Unpad Department of Statistics and the Department of Statistics of IPB.

Indrawati ES. (2015). Economic Status and Intensistas of Family Communication in Housewives at Kidul North Semarang Stage. Journal of Psychology Undip. 14(1):52-57

Latan H. (2012). Strutural Equation Modeling Concepts and Applications Using then Lisrel 8.80 Program. Bandung. Alphabet

Nainggolan, f , Viona and Lubis, j. (2019). Analysis of Factors Affecting the Sustainability of Pinang Farming, Master Program of Extension and Development Communication Study Program. IPB, Bogor.

Nainggolan Saidin, DMT Napitupulu and Saad Murdy. (2019). Technical Efficiency Study of People's Palm Oil Plantations in Jambi Province. Proceedings; ISBN : 978-60297051-8-8. Faculty of Agriculture, Jambi University. Things 529-547.

Thamrin, M. (2012). The Effect of Socioeconomic Factors on The Income of Pinang Farmers. Faculty of Agriculture, University of Muhammadiyah North Sumatra.

Tifansi, Holy. (2019). Socio-Economic Factors That Affect The Productivity of Palm Oil Farming in Kampung Sennah Village, Pangkatan District of Labuhanbatu Regency. Faculty of Agriculture, University of Muhammadiyah North Sumatra. 